\title{
The application of an in situ karyotyping technique for mesenchymal stromal cells: a validation and comparison study with classical G-banding
}

\author{
Sang Mee Hwang ${ }^{1,2}$, Cha-ja See ${ }^{2}$, Jungeun $\mathrm{Choi}^{3}$, Seon Young $\mathrm{Kim}^{2}$, Qute $\mathrm{Choi}^{2}$, Jung Ah Kim², \\ Jiseok Kwon ${ }^{4}$, Si Nae Park ${ }^{4}$, Kyongok Im ${ }^{4}$, Il-Hoan $\mathrm{Oh}^{5}$ and Dong Soon Lee $\mathrm{Le}^{2,4}$
}

The cytogenetic analysis of mesenchymal stromal cells (MSCs) is essential for verifying the safety and stability of MSCs. An in situ technique, which uses cells grown on coverslips for karyotyping and minimizes cell manipulation, is the standard protocol for the chromosome analysis of amniotic fluids. Therefore, we applied the in situ karyotyping technique in MSCs and compared the quality of metaphases and karyotyping results with classical G-banding and chromosomal abnormalities with fluorescence in situ hybridization (FISH). Human adipose- and umbilical cord-derived MSC cell lines (American Type Culture Collection PCS-500-011, PCS-500-010) were used for evaluation. The quality of metaphases was assessed by analyzing the chromosome numbers in each metaphase, the overlaps of chromosomes and the mean length of chromosome 1 . FISH was performed in the interphase nuclei of MSCs for $6 q, 7 q$ and $17 q$ abnormalities and for the enumeration of chromosomes via oligo-FISH in adipose-derived MSCs. The number of chromosomes in each metaphase was more variable in classical G-banding. The overlap of chromosomes and the mean length of chromosome 1 as observed via in situ karyotyping were comparable to those of classical G-banding $(P=0.218$ and 0.674 , respectively). Classical G-banding and in situ karyotyping by two personnel showed normal karyotypes for both cell lines in five passages. No numerical or structural chromosomal abnormalities were found by the interphase-FISH. In situ karyotyping showed equivalent karyotype results, and the quality of the metaphases was not inferior to classical G-banding. Thus, in situ karyotyping with minimized cell manipulation and the use of less cells would be useful for karyotyping MSCs.

Experimental \& Molecular Medicine (2013) 45, e68; doi:10.1038/emm.2013.133; published online 20 December 2013

Keywords: fluorescence in situ hybridization; in situ culture; karyotype; mesenchymal stromal cells

\section{INTRODUCTION}

The cytogenetic study of stem cells is an essential part of stem cell research and the clinical application of stem cells. ${ }^{1}$ In preclinical studies of stem cells, safety and the proof-ofprinciple for the desired therapeutic effect must be proven. $^{2,3}$ For safety testing, cytogenetic studies, specifically karyotypic analysis, is integral in testing for the toxicity and tumorigenicity of the stem cell. Although many studies report that stem cells are chromosomally stable, ${ }^{4}$ others report chromosomal abnormalities in prolonged or even in early passages. ${ }^{5-7}$ For mesenchymal stromal cells (MSCs), some studies identified chromosomal aberrations, while others did not. ${ }^{6,8-11}$ Aneuploidy with loss of chromosome $13^{6}$ or various chromosomal abnormalities including chromosomes $6,7,21$ or 22 were found in cultured MSCs. ${ }^{11}$ A large-scale analysis with gene expression data revealed abnormalities in chromosomes 6, 7, 13, 17 and 19 with approximately $4 \%$ incidence. $^{7}$ Therefore, obtaining karyotyping results at appropriate timing with adequate numbers of MSCs are essential.

Karyotyping stem cells require special attention because of the different characteristics of the cells and the available number of stem cells for chromosomal evaluation. Therefore, different protocols exist for different stem cells, namely, MSCs, human induced pluripotent stem cells and human embryonic stem cells. ${ }^{12,13}$

\footnotetext{
${ }^{1}$ Department of Laboratory Medicine, Seoul National University Bundang Hospital, Seongnam, Korea; ${ }^{2}$ Department of Laboratory Medicine, Seoul National University College of Medicine, Seoul, Korea; ${ }^{3}$ Department of Laboratory Medicine, Korea University Hospital, Seoul, Korea; ${ }^{4}$ Cancer Research Institute, Seoul National University College of Medicine, Seoul, Korea and ${ }^{5}$ Catholic High-Performance Cell Therapy Center, Department of Cellular Medicine, Research Center for Stem Cell Therapeutics Evaluation, Catholic University of Korea, Seoul, Korea

Correspondence: Dr DS Lee, Department of Laboratory Medicine, Seoul National University College of Medicine, 101 Daehakro, Seoul 110-744, Korea. E-mail: soonlee@snu.ac.kr
}

Received 29 June 2013; revised 26 August 2013; accepted 4 September 2013 
The in situ technique for culturing amniotic fluid cells has been performed since the $1970 s^{14-16}$ and has become the standard protocol for analyzing the chromosomes of amniotic fluids. ${ }^{17}$ Cells are grown on glass coverslips and adhere to the coverslips during harvesting and chromosome banding. The coverslips are mounted on microscope slides, and metaphases are viewed directly under the microscope, thus the cells remain 'in situ' on coverslips during the procedure. The in situ technique is the preferred method because it is reliable for evaluating mosaicisms ${ }^{18}$ and allows for the karyotyping of a fewer number of cells and minimizes the manipulation of cells compared with the classical flask culture method. ${ }^{17}$ We applied the in situ technique for karyotyping MSCs. In addition, the in situ karyotyping results were compared with fluorescence in situ hybridization (FISH).

The demand for identifying chromosomal abnormalities or genetic instability using a sensitive method is increasing. Although classical G-banding analysis is essential and useful in detecting chromosomal abnormalities, it can only be performed on divided cells and cannot be used to detect cryptic rearrangements or aberrations covering small regions. FISH can be used to detect abnormalities of smaller regions $(200 \mathrm{~kb}-2 \mathrm{Mb})$ and can be tested on interphase and metaphase nuclei. ${ }^{1}$ Thus, incorporating FISH as a test to verify chromosomal abnormalities can increase the sensitivity and accelerate the screening of chromosomal abnormalities in MSCs. Moreover, recurrent chromosomal aberrations noted in various studies can be detected using a combination of probes. $^{4,12}$

In this study, the in situ technique for karyotyping was applied in human MSCs and adherent tumor cell lines, and the method was validated with human MSCs. The results were compared with those of classical cytogenetic analyses. In addition, the numerical changes and specific structural changes commonly identified in MSCs were tested with FISH to increase the sensitivity for detecting chromosomal aberrations; these results were also compared with the in situ karyotyping results.

\section{MATERIALS AND METHODS MSCs}

A human adipose-derived MSC cell line (American Type Culture Collection (ATCC) PCS-500-011, ATCC, Manassas, VA, USA) and human umbilical cord-derived MSC cell line (ATCC PCS-500-010, ATCC) were used for validation studies. These MSCs were maintained in Mesenchymal Stem Cell Basal Medium (ATCC PCS-500-030, ATCC) and supplemented using the Mesenchymal Stem Cell Growth Kit (ATCC PCS-500-040, ATCC) according to the manufacturer's recommendation.

\section{Adherent cell lines}

Two cell lines possessing adherent growth properties with abnormal karyotypes were used for comparing the results of classical G-banding and in situ karyotyping. The cell lines used were DLD-1 and HCT 116 (ATCC), both human colorectal carcinoma cell lines with abnormal karyotypes.

\section{Classical G-banding}

Classical G-banding was performed according to the AGT cytogenetic laboratory manual. ${ }^{19}$ Briefly, a T25 culture flask containing $10 \mathrm{ml}$ of RPMI-1640 working media was placed in a $37^{\circ} \mathrm{C}$ water bath for 15 min before cell culture. A total $1 \times 10^{6}$ MSCs were cultured for $24 \mathrm{~h}$ in a $37^{\circ} \mathrm{C} \mathrm{CO}_{2}$ incubator. Colcemid solution $\left(0.1 \mu \mathrm{g} \mathrm{ml}^{-1}\right.$ at final concentration, KaryoMAX Colcemid Solution, Invitrogen, Grand Island, NY, USA) was added and placed at $37^{\circ} \mathrm{C}$ for an additional $50 \mathrm{~min}$ for cell cycle arrest at metaphase. The cells were treated with prewarmed hypotonic lysis solution $(0.075 \mathrm{M}$ or $0.054 \mathrm{M}$ potassium chloride $(\mathrm{KCl})$ ) at $37^{\circ} \mathrm{C}$ for less than $20 \mathrm{~min}$. The cells were fixed with Carnoy's solution $(3: 1(\mathrm{v} / \mathrm{v})$ methanol/glacial acetic acid) at room temperature. Metaphase slides were made by dropping cells on glass slides and the slides were placed in a $56{ }^{\circ} \mathrm{C}$ oven for $16 \mathrm{~h}$ and stained using Leishman's protocol. ${ }^{19}$

\section{In situ culture and karyotyping}

Approximately $1.5 \times 10^{5}$ MSCs were grown on $22 \times 22-\mathrm{mm}^{2}$ cover glass (Paul Marienfeld, Lauda-Königshofen, Germany) in each well on a 6-well dish (SPL, Pocheon, Korea) with Mesenchymal Stem Cell Basal Medium (ATCC) supplemented with Mesenchymal Stem Cell Growth Kit-Low serum (ATCC). At $16-24 \mathrm{~h}$ after cell seeding, the media were renewed. Once the confluence reached 50-70\%, chromosomes were harvested. Colcemid solution at a final concentration of $0.1 \mu \mathrm{g} \mathrm{ml}^{-1}$ (Invitrogen) was added and incubated in a $\mathrm{CO}_{2}$ incubator at $37^{\circ} \mathrm{C}$ for $40-50 \mathrm{~min}$. The media were removed, and $2 \mathrm{ml}$ of prewarmed $0.075 \mathrm{M}$ or $0.054 \mathrm{M} \mathrm{KCl}$ was added. The resulting mixtures were incubated in $37^{\circ} \mathrm{C} \mathrm{CO}_{2}$ for $30 \mathrm{~min}$. Freshly prepared of Carnoy's fixative solution $(200 \mu \mathrm{l})$ was added to the edge of the cover glass at room temperature for $2 \mathrm{~min}$. The solutions were removed, and $3 \mathrm{ml}$ of Carnoy's solution was added and left at room temperature for $20 \mathrm{~min}$. This step was repeated twice. The coverslip was mounted on the glass slide with the cells facing downward. The slide was placed in a $56^{\circ} \mathrm{C}$ oven for $16 \mathrm{~h}$ and stained using Leishman's protocol. ${ }^{19}$

\section{Comparison between classical G-banding and in situ karyotyping}

The karyotyping results of the adipose, umbilical cord-derived MSC cell lines and the adherent tumor cell lines were compared via classical G-banding and in situ karyotyping. Two independent personnel karyotyped MSCs for five passages. Two adherent tumor cell lines were karyotyped by two personnel per passage. The metaphases were analyzed according to the International System for Human Cytogenetic Nomenclature 2013. ${ }^{20}$

The quality of the metaphases via classical G-banding and in situ karyotyping was assessed with the adipose-derived MSCs at two different concentrations of hypotonic solution $(0.075 \mathrm{M}$ vs $0.054 \mathrm{M}$ $\mathrm{KCl})$. The parameters used for quality assessment were the number of chromosomes in each metaphase, the number of chromosome overlaps in a metaphase and the mean length of chromosome 1. The number of chromosomes in each metaphase was counted for 100 metaphases. The mean number of chromosomes in each metaphase was compared using the Mann-Whitney $U$-test, and the Leven test was performed for testing the equality of the variances of the two groups. The number of chromosomes with overlaps was assessed in 10 karyotyped cells, and the mean value of the number of overlaps was compared using the Mann-Whitney $U$-test. The chromosome overlaps were assessed in normal karyotype cells to evaluate the spread quality of the metaphases. The length of chromosome number 1 , which is the longest chromosome and is representative of the other 
chromosomes, was measured using the Metafer system (MetaSystems, Altlusseheim, Germany) and the length measurement tool to evaluate the readability or the resolution of each chromosome. The magnification was at $\times 63$, and the length was given in arbitrary units. The mean lengths of the classical G-banding and the in situ karyotyping were compared using the Mann-Whitney $U$-test (IBM SPSS Statistics 19 software, IBM, Somers, NY, USA).

\section{Additional FISH analysis of the interphase nuclei}

The specific structural abnormalities frequently identified in MSCs such as $6 \mathrm{q}$ deletion, $7 \mathrm{q}$ and $17 \mathrm{q}$ gain ${ }^{7,11}$ were evaluated using FISH in the interphase nuclei of both MSCs in two passages. The probes used were the Vysis LSI MYB (6q23) Spectrum AquaTM probe, Vysis D7S522/CEP 7 FISH, and Vysis TOP2A/CEP17 FISH probe (Abbott Laboratories, Abbott Park, IL, USA). A minimum of 200 interphase cells was counted.

The numerical abnormalities were evaluated via chromosome enumeration oligo-FISH (OF4-0127-0100, OF4-0128-0100, OF40129-0100, OF4-0052-0100, OF4-0130-0100, BP4-0131-0100; Cellay, Cambridge, MA, USA) in the interphase nuclei of the adipose-derived MSC in two passages according to the manufacturer's instruction. This interphase FISH included five oligonucleotide probe cocktails and one bacterial artificial chromosome probe cocktail. Briefly, FISH slides with MSCs fixed with Carnoy's solution were denatured with denaturing solution for $10 \mathrm{~min}$ at room temperature. The slides were dehydrated in a cold ethanol series. For the oligonucleotide probes, the probe cocktail was dropped onto the slide and the coverslip was placed. The slide was warmed at $37^{\circ} \mathrm{C}$ for $5-10 \mathrm{~min}$ and then immersed in $2 \times$ saline sodium citrate (SSC, $0.03 \mathrm{M}$ sodium citrate, $0.3 \mathrm{M} \mathrm{NaCl}, \mathrm{pH} 7.0$ ) for $5 \mathrm{~min}$ for hybridization. The coverslip was removed and placed in a wash solution containing 0.2 SSC and $0.1 \%$ sodium dodecyl sulfate. The slides were placed in $2 \times$ SSC at room temperature, and 4',6-diamidino-2-phenylindole was added. For the bacterial artificial chromosome FISH, the probe was denatured for $10 \mathrm{~min}$ at $72^{\circ} \mathrm{C}$ in a water bath, and was then immediately placed at $37^{\circ} \mathrm{C}$ for a minimum of $30 \mathrm{~min}$. Each slide was immersed in denaturation solution at $72{ }^{\circ} \mathrm{C}$ for $2 \mathrm{~min}$. The slides were dehydrated in an ethanol series ( 85 and 100\%, 1 min each) and air-dried. The FISH mixture was dropped on the slides, and the slides were stored at $37^{\circ} \mathrm{C}$ overnight for hybridization. The slides were placed in $2 \times$ SSC for $5 \mathrm{~min}$, the coverslips were removed and the slides were placed in a wash solution containing $0.4 \%$ SSC and $0.3 \%$ nonylphenol polyethylene glycol (NP-40) at $72{ }^{\circ} \mathrm{C}$ for $2 \mathrm{~min}$ followed by a second washing solution containing $2 \times$ SSC, $0.1 \%$ NP-40 for $2 \mathrm{~min}$. The slides were placed in $2 \times$ SSC at room temperature, and 4',6-diamidino-2-phenylindole was added. A minimum of 200 interphase nuclei was counted for each specimen. The value was compared with the reference value previously set using 20 non-manipulated MSCs.

\section{RESULTS}

The quality of metaphases as measured using classical G-banding and in situ karyotyping

The number of chromosomes within metaphases was counted in 100 metaphases for adipose-derived MSCs treated with different concentrations of hypotonic lysis solutions $(0.075 \mathrm{M}$ vs $0.054 \mathrm{M}$ ). Figure 1 shows the distribution of the number of chromosomes in each metaphase. The number of chromosomes was variable in classical G-banding, ranging from 25 to

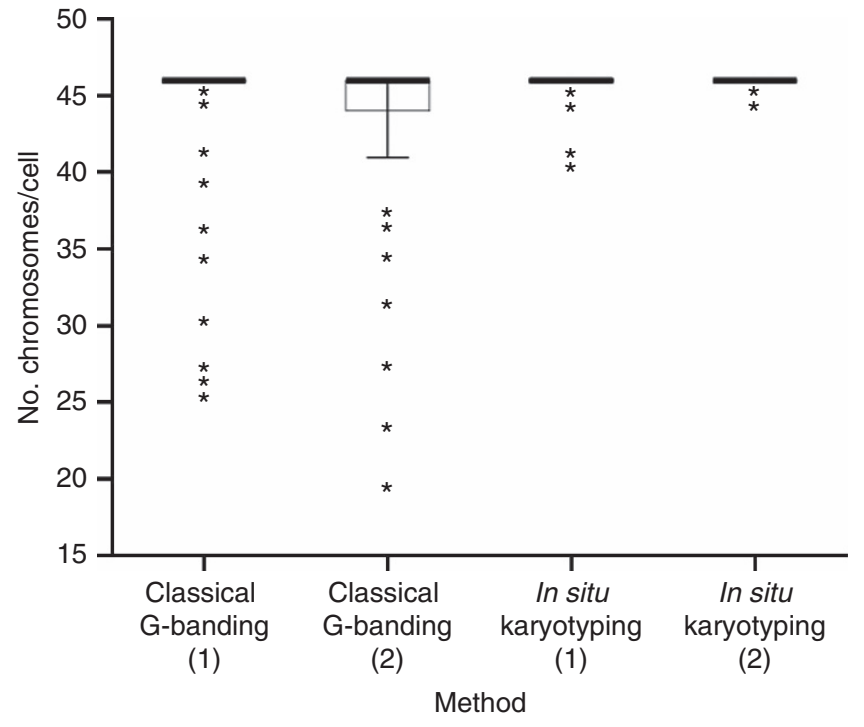

Figure 1 Distribution of the number of chromosomes in each metaphase using classical G-banding and in situ karyotyping. (1) Hypotonic solution with $0.075 \mathrm{~m} \mathrm{KCl}$ and (2) hypotonic solution with $0.054 \mathrm{~m} \mathrm{KCl}$.

46 chromosomes with $0.075 \mathrm{M} \mathrm{KCl}$ (condition 1) and 19-46 chromosomes with $0.054 \mathrm{M} \mathrm{KCl}$ (condition 2). However, the range was narrower using in situ karyotyping, showing 40-46 chromosomes in condition 1 and 44-46 chromosomes in condition 2. There were no significant differences in the range of chromosome numbers at different hypotonic solutions. The number of overlaps of chromosomes present in a metaphase was compared in 10 metaphases, and only the normal karyotype metaphases were included for the calculations (Figure 2). There were no significant differences in the number of chromosome overlaps between classical G-banding and in situ karyotyping $(P=0.218$ in $0.075 \mathrm{M} \mathrm{KCl}, P=0.123$ in $0.054 \mathrm{M} \mathrm{KCl})$. The difference in number of overlaps at two hypotonic conditions, regardless of the karyotyping methods, was not significant $(P=0.139)$. The length of chromosome 1 , which is the longest chromosome, was evaluated as a representative of the other chromosomes. With $0.075 \mathrm{M} \mathrm{KCl}$, in situ karyotyping showed longer chromosome lengths (107.4 arbitrary units (AR) vs 97.2 AR, $P=0.012$ ); however, with $0.054 \mathrm{M} \mathrm{KCl}$, classical G-banding showed longer chromosome lengths (107.7 vs $92.2 \mathrm{AR}, P=0.001)$. Comparing the karyotyping methods irrespective of the hypotonic solutions, there were no differences in the mean length of chromosome 1 between classical G-banding and in situ karyotyping $(P=0.674)$. Moreover, when comparing the results at two hypotonic conditions regardless of the karyotyping methods, the mean length of chromosome 1 was not different $(P=0.373)$.

Because there were no significant differences in the range of chromosome numbers, the extent of overlap or the chromosome length via two karyotyping methods (at $0.075 \mathrm{M}$ or $0.054 \mathrm{M} \mathrm{KCl}$ ), the former concentration commonly used for karyotyping analysis was used for the karyotyping studies. 


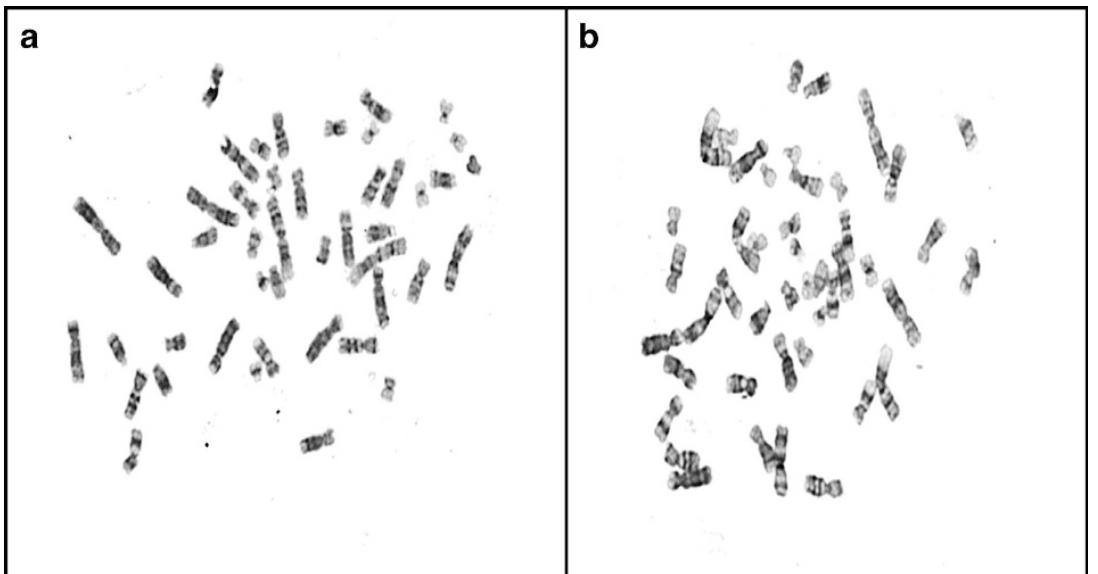

Figure 2 Chromosome overlaps in metaphases. Metaphases with (a) no overlap and (b) chromosome overlaps.

Table 1 The karyotyping results of mesenchymal stromal cell lines and other adherent cell lines via classical G-banding and in situ karyotyping

\begin{tabular}{|c|c|c|c|c|}
\hline \multirow[b]{2}{*}{ Type of MSCs } & \multicolumn{2}{|c|}{ Classical G-banding } & \multicolumn{2}{|c|}{ In situ karyotyping } \\
\hline & Personnel 1 & Personnel 2 & Personnel 1 & Personnel 2 \\
\hline \multicolumn{5}{|c|}{ Adipose-derived MSC cell line } \\
\hline A-MSC-1 & $46, \mathrm{XY}[20]$ & 46,XY[20] & $46, \mathrm{XY}[20]$ & $46, X Y[20]$ \\
\hline A-MSC-2 & $46, X Y[20]$ & $46, \mathrm{XY}[20]$ & $46, X Y[20]$ & $46, X Y[20]$ \\
\hline A-MSC-3 & $46, X Y[20]$ & $46, \mathrm{XY}[20]$ & $46, \mathrm{XY}[20]$ & $46, \mathrm{XY}[20]$ \\
\hline A-MSC-4 & $46, \mathrm{XY}[20]$ & $46, \mathrm{XY}[20]$ & $46, X Y[20]$ & $46, X Y[20]$ \\
\hline A-MSC-5 & $46, \mathrm{XY}[11]$ & $46, \mathrm{XY}[14]$ & $46, X Y[20]$ & $46, X Y[20]$ \\
\hline \multicolumn{5}{|c|}{ Cord-derived MSC cell line } \\
\hline C-MSC-1 & $46, \mathrm{XY}[20]$ & $46, \mathrm{XY}[15]$ & $46, X Y[20]$ & $46, X Y[20]$ \\
\hline C-MSC-2 & $46, X Y[20]$ & $46, \mathrm{XY}[20]$ & $46, \mathrm{XY}[20]$ & $46, \mathrm{XY}[20]$ \\
\hline C-MSC-3 & $46, \mathrm{XY}[20]$ & $46, \mathrm{XY}[20]$ & $46, \mathrm{XY}[20]$ & $46, X Y[20]$ \\
\hline C-MSC-4 & 46,XY[20] & $46, \mathrm{XY}[20]$ & $46, X Y[20]$ & $46, X Y[20]$ \\
\hline C-MSC-5 & $46, \mathrm{XY}[20]$ & $46, \mathrm{XY}[20]$ & $46, X Y[15]$ & $46, X Y[11]$ \\
\hline \multicolumn{5}{|c|}{ Adherent tumor cell line } \\
\hline DLD-1 & 46,XY,dup(2)(p13p22)[20] & 46,XY,dup(2)(p13p22)[20] & 46,XY,dup(2)(p13p22)[20] & 46,XY,dup(2)(p13p22)[20] \\
\hline HCT-116 & $\begin{array}{c}\text { 45,X, }-Y, \operatorname{der}(10) t(10 ; ?) \\
(q 26.1 ; ?), \operatorname{der}(16) t(16 ; ?) \\
(p 13.3 ; ?), \operatorname{der}(18) t(18 ; ?) \\
\quad(p 11.32 ; ?)[18] / \\
\text { 46,iden, }+Y[2]\end{array}$ & $\begin{array}{c}\text { 45,X, }-\mathrm{Y}, \operatorname{der}(10) t(10 ; ?)(\mathrm{q} 26.1 ; ?) \\
\operatorname{der}(16) \mathrm{t}(16 ; ?)(\mathrm{p} 13.3 ; ?) \\
\operatorname{der}(18) \mathrm{t}(18 ; ?)(\mathrm{p} 11.32 ; ?)[17] / \\
\text { 45,idem,inv(1)(p36.1q32.1)[3] }\end{array}$ & $\begin{array}{c}\text { 45,X, -Y,der(10)t(10;?) } \\
\text { (q26.1;?),der(16)t(16;?) } \\
\text { (p13.3;?),der(18)t(18;?) } \\
\quad \text { (p11.32;?)[15]/45, } \\
\text { idem,dup(5)(p13p15.1) } \\
\text { [3]/46,idem, + Y[2] }\end{array}$ & $\begin{array}{c}\text { 45,X, }-Y, \operatorname{der}(10) t(10 ; ?) \\
(q 26.1 ; ?), \operatorname{der}(16) t(16 ; ?) \\
(p 13.3 ; ?), \operatorname{der}(18) t(18 ; ?) \\
\quad(p 11.32 ; ?)[20]\end{array}$ \\
\hline
\end{tabular}

Abbreviation: MSC, mesenchymal stromal cell.

\section{Karyotype results}

The results of the classical G-banding and in situ karyotyping of the two MSCs at five passages and the two adherent cell lines are shown in Table 1. Both methods showed normal diploid karyotype when used by two independent researchers for two MSCs. The DLD-1 cell line was karyotyped as 46,XY,dup (2)(p13p22) 20 by two personnel by both in situ karyotyping and classical G-banding. Two personnel karyotyped the HCT-116 cell line with $45, \mathrm{X},-\mathrm{Y}, \operatorname{der}(10) \mathrm{t}(10 ; ?)$ $(\mathrm{q} 26.1 ; ?), \quad \operatorname{der}(16) \mathrm{t}(16 ; ?)(\mathrm{p} 13.3 ; ?), \operatorname{der}(18) \mathrm{t}(18 ; ?)(\mathrm{p} 11.32 ; ?) \quad$ as the mainline. One researcher identified more sidelines using in situ karyotyping, and another researcher identified more sidelines using classical G-banding.

\section{FISH results}

Additional tests to identify chromosomal abnormalities in the interphase nuclei of MSC cell lines are shown in Tables 2 and 3. Because of the similar centrometric sequence of 
Table 2 The results of FISH for enumerating chromosomes in adipose-derived MSCs

\begin{tabular}{lcccccccrrrr}
\hline & \multicolumn{10}{c}{ Normal signal (\%) } \\
\cline { 2 - 9 } Cell & Chr. 1 & Chr. 2 & Chr. 3 & Chr. 4 & Chr. 5 & Chr. 6 & Chr. 7 & Chr. 8 & Chr. 9 & Chr. 10 \\
\hline A-MSC-1 & 100.0 & 98.0 & 98.0 & 99.0 & 99.0 & 98.0 & 98.0 & 98.0 & 98.0 & 99.0 \\
A-MSC-5 & 100.0 & 98.0 & 96.0 & 100.0 & 99.0 & 98.0 & 98.0 & 98.0 & 98.0 & 100.0 \\
& Chr. 11 & Chr. 12 & Chr. 13/21 & Chr. 14/22 & Chr. 15 & Chr. 16 & Chr. 17 & Chr. 18 & Chr. 19 & Chr. 20 \\
& 98.0 & 96.0 & 98.0 & 96.0 & 99.0 & 98.0 & 97.0 & 96.0 & 100.0 & 98.0 \\
A-MSC-1 & 97.0 & 97.0 & 94.0 & 99.0 & 99.0 & 98.0 & 99.0 & 98.0 & 100.0 & 97.0 \\
A-MSC-5 & 97.0 &
\end{tabular}

Abbreviations: FISH, fluorescence in situ hybridization; MSC, mesenchymal stromal cell.

aResults $\geqslant 94 \%$ are considered to be within a normal limit.

Table 3 Interphase FISH results for $6 q, 7 q$ and $17 q$ abnormalities in MSC cell lines

\begin{tabular}{lccc}
\hline & \multicolumn{3}{c}{ Normal signala $^{\mathrm{a}}$} \\
\cline { 2 - 4 } Cell & $6 q(\%)$ & $7 q(\%)$ & $17 q(\%)$ \\
\hline A-MSC-1 & 97.5 & 98.5 & 97.0 \\
A-MSC-5 & 97.5 & 99.0 & 99.5 \\
C-MSC-1 & 98.5 & 98.0 & 98.0 \\
C-MSC-5 & 99.0 & 98.5 & 99.0 \\
\hline
\end{tabular}

Abbreviations: FISH, fluorescence in situ hybridization; MSC, mesenchymal stromal cell.

aResults $\geqslant 94 \%$ are considered to be within a normal limit.

chromosomes (13/21 and 14/22), these chromosomes could not be separately identified. The Oligo-FISH performed in two passages of the adipose-derived MSC cell line was normal for all of the chromosomes. Additional FISH to detect abnormalities of the $6 \mathrm{q}$ deletion, $7 \mathrm{q}$ and $17 \mathrm{q}$ gain frequently identified in MSCs were within normal limits for both MSCs, as observed in two passages.

\section{DISCUSSION}

In situ karyotyping was applied in MSC karyotyping and showed the same karyotype results as those for classical G-banding with fewer cells and less variation in the number of chromosomes present in each metaphase. Moreover, the mean length of chromosome 1 was not shorter, and the overlap of chromosomes was not significantly greater than those in classical G-banding.

Hypotonic solutions are thought to be essential for wellspread metaphase chromosomes because they move chromosomes to the periphery of the cells, thus allowing for the stretching of chromosomes during mitotic swelling. ${ }^{21}$ Therefore, we performed experiments using two different concentrations of hypotonic solutions to determine whether the concentration of hypotonic solution affects the quality of metaphases in in situ karyotyping and classical G-banding. However, depending on the concentration of the hypotonic solutions, some parameters for assessing the quality of metaphases were superior using classical G-banding, and other parameters were superior when using in situ karyotyping. Thus, either concentration of hypotonic solution can be used, but because most cytogenetic analyses are performed with $0.075 \mathrm{M} \mathrm{KCl}$, laboratories would likely prefer to use the usual concentration. The variation of chromosome numbers in each metaphase was significantly reduced in in situ karyotyping, regardless of the concentration of hypotonic solutions. This is explainable partly due to the difference in making metaphase slides by the two methods. Although classical G-banding requires cells to be dropped from a distance for preparing slides, in situ karyotyping uses cells grown on coverslips of the slides that are used directly. Cell manipulation may create a source of stress; ${ }^{22,23}$ thus, a less manipulative method such as the in situ technique may be preferable.

The karyotype results from classical G-banding and in situ karyotyping were identical in the MSC cell lines with the exception of the number of clones available for karyotyping in certain passages, for example, 46,XY[11] vs 46,XY[14]. Although many studies have reported chromosomal instability with sensitive methods such as FISH or microarray, ${ }^{6,7,11}$ the MSC cell lines used in this study showed no abnormalities via karyotype or interphase FISH. Limited testing performed with a few passages with only two cell lines may be the reason for this. However, selecting certain probes or using enumeration FISH probes appears to be useful in testing for the abnormalities in the interphase nuclei, as false negative results may arise because of the karyotyping of metaphases because fewer than 50 metaphases are usually analyzed for karyotyping and because discrepant results are found in hematologic malignancies and in the prenatal testing of interphase and metaphase nuclei. ${ }^{24,25}$

The current study included MSC cell lines of normal karyotypes, and thus the sensitivity of identifying abnormal clones could not be verified for in situ karyotyping, which is known to identify mosaicisms more sensitively ${ }^{17}$ as well as for FISH, which identifies abnormalities of small regions. However, the evaluation of adherent tumor cell lines with abnormal karyotypes showed comparable results between classical G-banding and in situ karyotyping. The DLD-1 cell line was karyotyped identically using both methods, and the major abnormal clone of the HCT-116 cell line was identical 
via both methods. However, the subclones differed depending on the personnel and the method. This finding suggests that in situ karyotyping is also useful in identifying abnormal clones; thus, the in situ technique would be widely applicable in adherent cell lines as well. Further studies on MSCs with abnormalities may be necessary to determine their sensitivity in identifying abnormal clones.

This study validated that the in situ karyotyping technique, which has previously been used for the chromosome analyses of amniotic fluids, can be used as an alternative method in karyotyping MSCs. The in situ technique takes advantage of MSCs that have adherent characteristics ${ }^{26}$ and are thus good candidates for this method. Compared with classical G-banding, in situ karyotyping produced similar metaphase quality as well as equivalent karyotype results that could be widely applicable to MSCs.

\section{ACKNOWLEDGEMENTS}

This study was supported in part by (1) a grant (10172KFDA993) from the Korea Food and Drug Administration in 2011, (2) the Korean Health Technology R\&D Project, Ministry of Health and Welfare, Republic of Korea (A120216) and from (3) the Basic Science Research Program through the National Research Foundation of Korea (NRF), Funded by the Ministry of Education, Science and Technology (2012-0002257).

1 Catalina, P, Cobo, F, Cortes, JL, Nieto, AL, Cabrera, C, Montes, R et al. Conventional and molecular cytogenetic diagnostic methods in stem cell research: a concise review. Cell. Biol. Int. 2007; 31: 861-869.

2 National Institutes of Health Stem Cells: Scientific Progress and Future Research Directions. Department of Health and Human ServicesJune, 2001. Available from http://stemcells.nih.gov/info/2001report/pages/ chapter10.aspx

3 Goldring, CE, Duffy, PA, Benvenisty, N, Andres, PW, Ben-David, U, Eakins, $\mathrm{R}$ et al. Assessing the safety of stem cell therapeutics. Cell Stem Cell 2011; 8: 618-628.

4 Grimes, BR, Steiner, CM, Merfeld-Clauss, S, Traktuev, DO, Simth, D, Reese, A et al. Interphase FISH demonstrates that human adipose stromal cells maintain a high level of genomic stability in long-term culture. Stem Cells Dev. 2009; 18: 717-724.

5 Taapken, SM, Nisler, BS, Newton, MA, Sampsell-Barron, TL, Leonhanrd, $\mathrm{KA}$, Mclntire, EM et al. Karyotypic abnormalities in human induced pluripotent stem cells and embryonic stem cells. Nat. Biotechnol. 2011; 29: 313-314.

6 Takeuchi, M, Takeuchi, K, Ozawa, Y, Kohara, A, Mizusawa, H. Aneuploidy in immortalized human mesenchymal stem cells with non-random loss of chromosome 13 in culture. In Vitro Cell Dev. Biol. Anim. 2009; 45: 290-299.

7 Ben-David, U, Mayshar, Y, Benvenisty, N. Large-scale analysis reveals acquisition of lineage-specific chromosomal aberrations in human adult stem cells. Cell Stem Cell 2011; 9: 97-102.

8 Bernardo, ME, Zaffaroni, N, Novara, F, Cometa, AM, Avanzini, MA, Moretta, A et al. Human bone marrow-derived mesenchymal stem cells do not undergo transformation after long-term in vitro culture and do not exhibit telomere maintenance mechanisms. Cancer Res. 2007; 67: 9142-9149.

9 Røsland, GV, Svendsen, A, Torsvik, A, Sobala, E, McCormack, E, Immervoll, $\mathrm{H}$ et al. Long-term cultures of bone marrow-derived human mesenchymal stem cells frequently undergo spontaneous malignant transformation. Cancer Res. 2009; 69: 5331-5339.

10 Ueyama, H, Horibe, T, Hinotsu, S, Tanaka, T, Inoue, T, Urushihara, $\mathrm{H}$ et al. Chromosomal variability of human mesenchymal stem cells cultured under hypoxic conditions. J. Cell. Mol. Med. 2012; 16: 72-82.

11 Buyanovskaya, O, Kuleshov, N, Nikitina, V, Voronina, EX, Katosova, LD, Bochkov, NP. Spontaneous aneuploidy and clone formation in adipose tissue stem cells during different periods of culturing. Bull. Exp. Biol. Med. 2009; 148: 109-112.

12 Meisner, L, Johnson, J. Protocols for cytogenetic studies of human embryonic stem cells. Methods 2008; 45: 133-141.

13 Moralli, D, Yusuf, M, Mandegar, MA, Khoja, S, Monaco, ZL, Volpi, EV. An improved technique for chromosomal analysis of human ES and iPS Cells. Stem Cell Rev. 2011; 7: 471-477.

14 Bui, TH, Iselius, L, Lindsten, J. European collaborative study on prenatal diagnosis: mosaicism, pseudomosaicism and single abnormal cells in amniotic fluid cell cultures. Prenal. Diagn. 1984; 4: 145-162.

15 Peakman, DC, Moreton, MF, Corn, BJ, Robinson, A. Chromosomal mosaicism in amniotic fluid cell cultures. Am. J. Hum. Genet. 1979; 31: 149-155.

16 Schmid, W. A technique for in situ karyotyping of primary amniotic fluid cell cultures. Humangenetik 1975; 30: 325-330.

17 Minehart, PM. Preparation, culture, and analysis of amniotic fluid samples. Curr. Protoc. Hum. Genet 2012. Chapter 8: Unit 8.4. doi:10.1002/ $0471142905 . h g 0804 s 74$.

18 Hirsh, B, Brothman, AR, Jacky, PB, Rao, KW, Wolff, DJ. Section E6 of the ACMG technical standards and guidelines: Chromosome studies for acquired abnormalities. Genet. Med. 2005; 7: 509-514.

19 Barch, MJ, Knutsen, T, Spurbeck, JL. The AGT Cytogenetics Laboratory Manual. Lippincott-Raven: Philadelphia, PA, USA, 1997.

20 Shaffer, LG, McGowan-Jordan, J, Schmid, M (eds) ISCN 2013: An International System for Human Cytogenetic Nomenclature (2013): Recommendations of the International Standing Committee on Human Cytogenetic Nomenclature. Karger: Basel, Switzerland, 2013.

21 Claussen, U, Michel, S, Muhlig, P, Westerman, M, Grummt, UW, KromeyerHauschild, $\mathrm{K}$ et al. Demystifying chromosome preparation and the implications for the concept of chromosome condensation during mitosis. Cytognenet Genome Res. 2002; 98: 136-146.

22 Wang, H, Riha, GM, Yan, S, Li, M, Chai, H, Yang, H, et al. Shear stress induces endothelial differentiation from a murine embryonic mesenchymal progenitor cell line. Arterioscler. Thromb. Vasc. Biol. 2005; 25: 1817-1823.

23 Lee, IC, Wang, JH, Lee, YT, Young, TH. The differentiation of mesenchymal stem cells by mechanical stress or/and co-culture system. Biochem. Biophys. Res. Commun. 2007; 352: 147-152.

24 Toutain, J, Epiney, M, Begorre, M, Dessuant, H, Vandenbossche, F, Horovitz, J, et al. First-trimester prenatal diagnosis performed on pregnant women with fetal ultrasound abnormalities: the reliability of interphase fluorescence in situ hybridization (FISH) on mesenchymal core for the main aneuploidies. Eur. J. Obstet. Gynecol. Reprod. Biol. 2010; 149: $143-146$.

25 Tanaka, K, Arif, M, Eguchi, M, Shintani, T, Kumaravel, TS, Asaoku, H et al. Interphase fluorescence in situ hybridization overcomes pitfalls of G-banding analysis with special reference to underestimation of chromosomal aberration rates. Cancer Genet. Cytogenet. 1999; 115: 32-38.

26 Dominici, M, Le Blanc, K, Mueller, I, Staper-Cortenbach, I, Marini, F, Krause, $\mathrm{D}$ et al. Minimal criteria for defining multipotent mesenchymal stromal cells. The International Society for Cellular Therapy position statement. Cytotherapy 2006; 8: 315-317.

(c) (1) $\odot$ This work is licensed under a Creative Commons Attribution-NonCommercial-NoDerivs 3.0 Unported License. To view a copy of this license, visit http:// creativecommons.org/licenses/by-nc-nd/3.0/ 